\title{
"I Am Not Punjabi, My Parents Are": Degradation of the language OF DOMINANT MAJORITY
}

\author{
Sham HAIDAR \\ Air University Islamabad, Pakistan \\ sham_haidar@yahoo.com \\ Tehreem TAHIR \\ Air University Islamabad, Pakistan \\ tehrim.3@gmail.com
}

\author{
Tehreem WALI \\ Riphah International University, Pakistan \\ tehreemwali689@gmail.com \\ Mehwish PARVEEN \\ Air University Islamabad, Pakistan \\ mehwishparveen89@gmail.com
}

\begin{abstract}
Due to social and geographical mobility and globalization, many minority languages in the world are pushed to the periphery. Reasons for such a trend differ among languages. In the case of the Punjabi language, despite being spoken by a major portion of the population, the speakers are gradually disowning it. Considering this gradual shift, the present study explores the predicament of the Punjabi language. The study uses phenomenological design and collects data from Punjabi ethnic students in four different universities in Islamabad. The study uses semi-structured interviews, TV shows, and natural conversations. Findings reveal that the Punjabi speakers themselves disown their language as well as Punjabi identity due to social, economic, religious, and political reasons. Especially women avoid the language more, they do not speak Punjabi with their children, and they reject their Punjabi identity.
\end{abstract}

Keywords: language ideology; linguistic identity; linguicide; ethnic identity; domain of use

\section{Povzetek}

Zaradi družbene in geografske mobilnosti in globalizacije so številni manjšinski jeziki na svetu potisnjeni na obrobje. Razlogi za to se razlikujejo. V primeru pandžabskega jezika se govorci kljub temu, da jih govori večji del prebivalstva, pandžabščini postopoma odpovedujejo. Glede na ta postopni premik študija raziskuje težave pandžabskega jezika. Študija uporablja fenomenološko zasnovo in zbira podatke študentov pandžabskih narodnosti na štirih različnih univerzah v večjezičnem in večkulturnem glavnem mestu Islamabad. Študija uporablja pol strukturirane intervjuje, televizijske oddaje in naravne pogovore. Študija ugotavlja, da se govorci pandžabščine sami odpovedujejo svojemu jeziku in pandžabski identiteti iz družbenih, ekonomskih, verskih in političnih razlogov. Še posebej ženske se jezika bolj izogibajo, s svojimi otroki ne govorijo $v$ pandžabščini in zavračajo svojo pandžabsko identiteto.

Ključne besede: jezikovna ideologija; jezikovna identiteta; lingicid; etnična identiteta; domena uporabe

Acta Linguistica Asiatica, 11(2), 2021.

ISSN: 2232-3317, http://revije.ff.uni-lj.si/ala/

DOI: 10.4312/ala.11.2.101-127 


\section{Introduction}

At the global level, languages have been dying at a shocking rate for the past few decades (Abley, 2003; Crystal, 2000; Dalby, 2003; Gibbs, 2002; Nettle \& Romaine, 2000). According to some linguists, $60-90 \%$ of the world's total number of languages are likely to die out within present century, approximately at the rate of one language every two weeks (Crystal, 2000). The effect can be seen as trickling down to the level of individual countries, including Pakistan. Pakistan is a multilingual country (Rahman, 2010) with approximately 70 languages (Census, 2017). Unfortunately, most of these languages are facing the threat of extinction. According to the Ethnologue, 13 languages of Pakistan fall under the category of threatened languages or even lower according to the GID scale (Fishman, 1991).

The phenomenon of language death in Pakistan seems to have taken a political turn in the form of linguicide (Phillipson \& Skutnabb, 1995). For instance, in Pakistan's linguistic scenario, Urdu and English are considered the languages of prestige; on the contrary, other regional languages are being marginalized and pushed to particular domains of use (Mansoor, 2004). Punjabi is the most spoken language being the language of $38.78 \%$ of the total population (Census, 2017). However, due to globalization, state policy and religious affiliation, the speakers of the Punjabi language are turning towards national and official languages, Urdu and English, respectively. The speakers of Punjabi have shrunk to $38.78 \%$ (Census, 2017) from $44.10 \%$ (Census, 1998). Urdu and English are spoken by a relatively small part of the population and used primarily for education. It is usually the majority language(s) that threatens the existence of minority languages (Nettle \& Romaine, 2000). However, in our paper, we argue that the languages of a minor group, Urdu and English, are taking over the language of a majority group, Punjabi. In Pakistan, Urdu is used as the language of instruction in government schools, whereas in elite schools, the English language is used as the medium of instruction (Haidar, 2016, 2019; Rahman, 2010). Despite being spoken by a major part of the population, Punjabi is not given the equivalent status as Urdu or English. Mansoor (2004) argues that there are no educational programs initiated by the Higher education commission in which any subject identified with local or regional languages has been taught in schools. Moreover, according to Mansoor's study, students are kept ignorant of the significance of their local languages. However, the Sindh government has taken up several steps to promote their language through their educational institutes by declaring the Sindhi language as a compulsory subject in elementary schools.

This paper probes into the problem of decline in the usage of the Punjabi language among young generations and attempts to identify the causes leading to this degradation. Previous studies have explored the declining status of Punjabi language through the lens of colonization and Islamization (Jalal, 1995; Rammah, 2006; Zaidi, 2010), lack of governmental support (Mansoor, 2004), loss of intergenerational 
transmission (Nazir, Aftab \& Saeed, 2013), the issue of intellectual death (Khokhlova, 2014; Jaffrelot, 2002; Shafi, 2013), and the loss of lexicon (Din \& Ghani, 2017). The current study explores the attitude of Punjabi speakers towards the language, which may lead to a decline in the usage of the Punjabi language. This study involves young people from the region of Islamabad, the capital city that offers a wide range of ethnic diversity compared to other cities. The study participants are young as it is argued that younger generations often avoids Punjabi as compared to older generations (Gillani \& Mahmood, 2014; Romaine 1995). Therefore, we intend to approach the phenomenon from the perspective of young people.

This study argues that the relative positioning of languages in Pakistan per their status and prestige is leading to several issues. One such problem links with the status attached to Punjabi. Although it is one of the major languages of Pakistan, Punjabi is not given much attention. It is oftenused to induce humor in everyday conversations, whereas English and Urdu are seen as the languages of knowledge and power. This situation leads to the gradual dismissal of the Punjabi language by the Punjabi speakers. The mechanisms of abandonment restrain Punjabi to the domains of informal use only.

\subsection{History of Pakistani Punjabi (West Punjabi)}

The current situation of Punjabi in Pakistan cannot be detached from its historical progression. The notion that Punjabi is being marginalized even by its own speakers can be traced back to the history of the subcontinent (India, Pakistan, and Bangladesh before 1947). Jalal (1995) traces the predicament of the Punjabi language by drawing an analogy between Punjabis and Heer of Waris Shah ${ }^{1}$. Like Heer, Jalal argues, Punjabis were so lost in love for the new land and a place of belonging that they forgot or overlooked their ethnic ties. She further states that Punjabis adopted the slogan, "speak Urdu, read Urdu, write Urdu" (p. 84), at the prospect of recovering their lost identity through Pakistan. At the time of partition, the Punjabi community living in Pakistan collaborated with the Muhajirs to make Urdu a national language of the new country (Jalal, 1995).

Another factor that plays an important role in marginalizing Punjabi in Pakistan's linguistic landscape is the association of anti-Islamic ideologies with the language. For example, the heroes celebrated by the Punjabis are usually against the Muslims, such as Dullah Bhatti and Maharajah Ranjit Singh. Moreover, the Punjabi language, being the language of the Sikh community, is also considered to be inappropriate for Muslim

\footnotetext{
${ }^{1}$ Heer Ranjha is a folk tale, retold in poetic form by renowned Punjabi poet, Waris Shah. The story traces the tragic romance between the protagonists, Heer and Ranjha, who belong to different castes but fall in love despite facing opposition from their relatives. The story ends with Heer being poisoned and Ranjha committing suicide by consuming the same poison.
} 
religious practices. Therefore, when President Zia-ul- Haq started the process of Islamization in the country, he excluded the Sikh writers from the curriculum of Masters in Punjabi, which was offered at the Punjab University, Lahore, at the time. Moreover, a Punjabi language campaigner, Muhammad Masud (1916-85), once decided to offer prayers in Punjabi instead of Arabic. He was thrown out of the mosque by his fellow Punjabi worshippers (Zaidi, 2010). Lastly, the paradox of the Punjabi movement is also very significant. The motto of the Punjabi movement is not the promotion of their language, but only the concern about the cultural shame that is associated with the language. Punjabi speakers hide under the cloak of being in the majority and argue that if they promote their language to any status, other minority ethnic groups will fight back. An example of this would be an incident at the provincial assembly of Punjab when a Punjabi legislator, Fazal Hussain, insisted upon taking the oath in his mother tongue and it resulted in a linguistic riot despite all present there were Punjabis (Zaidi, 2010).

According to Khokhlova (2014), the languages which are at the risk of endangerment due to their lack of use by the speakers are known as dying languages. This abandonment of language could be due to reasons such as migration, globalization, state policies, pressure by majority language(s), political pressure, search for professional opportunities, and others. Being a language of a majority group, Punjabi has been faced with another kind of death/shift that is intellectual death. Nazir et al. (2013) have provided a few reasons for the intellectual death of the Punjabi language in Pakistan. According to them, Punjabi is not being passed on to younger generations because parents think that it lacks prestige, and Bourdieu (1991) states that social and economic prestige contributes to the survival of a language. Punjabi parents are of the view that their language does not have any economic benefits, which is why proficiency in Punjabi would lead nowhere in the job market, neither it would help their children ascend academically (Jaffrelot, 2002).

The stigma attached to the Punjabi language bans the speakers to own their language (Shafi, 2013). An informal term, "paendo," meaning a person of crude manners, is used for those who speak Punjabi (Shafi, 2013, p. 40). This term holds negative connotations and is usually intended as an insult for a person who even remotely displays Punjabi traditional ethnic behavior. The above-discussed dimensions dealing with chronological and social decline of Punjabi sum up the existing research in the field.

\subsection{Goal of the current study}

The current paper examines the decline in the usage of the Punjabi language among young generations. The focus of this study is to explore the contemporary factors responsible for the gradual decline in the usage of Punjabi among the youth. The study 
includes interviews with young university students and audio-recordings of natural conversations with Punjabi families.

\section{Theoretical framework}

The theoretical framework follows the theories of linguicide (Phillipson \& Skutnabb, 1995), symbolic power of language (Bourdieu, 1991), and sociolinguistics of globalization (Blommaert, 2010). The concepts of language death and linguicide look at the extinction of languages differently. The concept of language death is something natural and inevitable, whereas linguicide is a forceful act initiated by some kind of power. An example of such forceful act is an ideological division of linguistic groups. The process of linguicism is evident in the process of colonization. For instance, the colonial authorities stigmatized the use of indigenous languages in India (Viswanathan, 2014). Phillipson and Skutnabb (1995) argue that the agent involved in linguicide can be either active (making attempts at killing the language) or passive (letting the language die). These theoretical insights will be utilized to scrutinize the situation faced by the Punjabi language in the Pakistani context of usage.

Bourdieu's notion of the symbolic power of a language states that a dominant class imposes their language as the standard language on speakers of other languages, which further dominates them. Languages of dominated classes thus become valueless in formal situations and people need to acquire a dominant language for their survival in education and social life (Bourdieu, 1991). For instance, in the Pakistani context, the language of prestige is English, and all other languages are defined in relation to English (Haidar, 2019). In Pakistan, Urdu comes second, therefore, directly affecting the status of regional languages, which belong to even lower positions.

However, studies (e.g., Blommaert, 2010; Dewey, 2007; Saxena \& Omoniyi 2010) problematize the fact that Bourdieu's argument revolves around the static elements of prestige attached to a language, which cause the marginalization of other relatively situated languages. Therefore, we also consider Blommaert's (2010) theory on sociolinguistics of globalization. Blommaert's theory elaborates on the ever-changing nature of the notion of prestige. According to him, the prestige attached to one language is not upheld in the same manner in all contexts. This insight will help us to scrutinize the fluctuating status of Punjabi in differing contexts. The value of each language changes from location to location, context to context, and situation to situation. The oscillating nature of prestige, which gets affected by several factors, is charted out in the form of a scale that Blommaert calls the sociolinguistic scale and relates it to the concept of polycentricity.

The converging point of all the three theories is the role of language in upholding social dominance and people's acceptance of some languages while rejecting others. Henceforth, these theories help us to understand the power struggle among different 
languages that results in the marginalization of the language of the majority (Punjabi) in Pakistan.

\section{Methodology}

The study uses the interpretivist paradigm. We collected data through qualitative interviews and observations in a natural environment to understand participants' perceptions of Punjabi (Sandberg, 2000). It is also a phenomenological study since we explored the phenomenon of degradation of the Punjabi language by getting to know participants' "lived experiences" (Creswell, 2012, p. 26). Finally, the phenomenological aspect of the study provides an insight into the meaning-making process regarding the youth's view of the Punjabi language (Creswell, 2012).

\subsection{Data collection}

Our data collection consists of semi-structured, open-ended, and informal interviews and their audio recordings. We also examined recorded natural conversations of Punjabi families.

\subsection{Participants}

Participants in interviews were students aged 18 to 22 from four universities in Islamabad as shown in Table 1. These universities were selected based on their popularity and for having students from different linguistic backgrounds. The medium of instruction in all four universities is English. The total number of participants is 60, and includes male and female participants, as elaborated in Table 2. The number of male participants was greater due to the reluctance of the female participants. Namely, several females rejected their participation due to their Punjabi identity, which we will elaborate further in the analysis part of the study. We selected 15 participants from each university with an uneven ratio of male and female participants, which is further clarified in the table below. Students having Punjabi ethnicity were purposively selected for the interviews. Participants for the natural conversation recordings were family members of 5 Punjabi households and were aged 5 to 60 . The reason for selecting this age group was to explore the involvement of parents in the decline of Punjabi language usage among youth. 
Table 1: Details of the universities where data was collected

\begin{tabular}{lccc}
\hline University & No. of part. & Male/Female & Age limit \\
\hline $\begin{array}{l}\text { University A (A public sector university } \\
\text { established and managed by the military) }\end{array}$ & 15 & $14 / 1$ & $18-21$ \\
$\begin{array}{l}\text { University B (A public sector university } \\
\text { established and managed by the military) }\end{array}$ & 15 & $9 / 6$ & $20-21$ \\
University C (A public sector international univ.) & 15 & $7 / 8$ & $19-22$ \\
University D (A public sector University) & 15 & $12 / 3$ & $18-22$ \\
Total & $\mathbf{6 0}$ & $\mathbf{4 2 / 1 8}$ & \\
\hline
\end{tabular}

Table 2: details of the study participants

\begin{tabular}{|c|c|c|c|c|c|}
\hline Univ. & Participant & Gender & Age & Education Level & Language of Interview \\
\hline \multirow{15}{*}{ 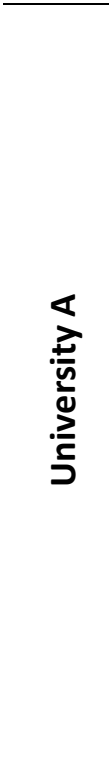 } & P1 & $M$ & 20 & Undergraduate & Urdu \\
\hline & $\mathrm{P} 2$ & $M$ & 20 & Undergraduate & Punjabi/Urdu \\
\hline & P3 & $M$ & 19 & Undergraduate & Punjabi/Urdu \\
\hline & P4 & $M$ & 21 & Post-graduate & Punjabi/Urdu/English \\
\hline & P5 & $M$ & 19 & Undergraduate & Urdu/English \\
\hline & P6 & $M$ & 21 & Undergraduate & Urdu/English \\
\hline & P7 & $M$ & 20 & Undergraduate & Urdu/English \\
\hline & P8 & $M$ & 18 & Undergraduate & Urdu/English \\
\hline & P9 & $M$ & 18 & Undergraduate & Punjabi \\
\hline & P10 & $M$ & 18 & Undergraduate & Urdu \\
\hline & P11 & $M$ & 18 & Undergraduate & Urdu/English \\
\hline & P12 & $M$ & 19 & Undergraduate & Urdu \\
\hline & P13 & $M$ & 20 & Undergraduate & Urdu/English \\
\hline & P14 & $M$ & 19 & Undergraduate & Punjabi/English \\
\hline & P15 & $\mathrm{F}$ & 19 & Undergraduate & Urdu/English \\
\hline \multirow{15}{*}{ 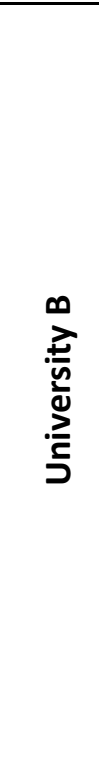 } & P16 & $M$ & 21 & Undergraduate & English \\
\hline & P17 & $M$ & 21 & Undergraduate & Urdu/English \\
\hline & P18 & $M$ & 20 & Undergraduate & Urdu \\
\hline & P19 & $\mathrm{F}$ & 21 & Undergraduate & Urdu \\
\hline & P20 & $\mathrm{F}$ & 21 & Undergraduate & Urdu/English \\
\hline & P21 & $M$ & 21 & Undergraduate & Punjabi/English \\
\hline & P22 & $\mathrm{F}$ & 20 & Undergraduate & Urdu/English \\
\hline & P23 & $M$ & 20 & Undergraduate & Urdu \\
\hline & P24 & $M$ & 20 & Undergraduate & Urdu \\
\hline & P25 & $M$ & 20 & Undergraduate & English \\
\hline & P26 & $\mathrm{F}$ & 20 & Undergraduate & Urdu/English \\
\hline & P27 & $M$ & 21 & Undergraduate & Urdu \\
\hline & P28 & $M$ & 21 & Undergraduate & Urdu/English \\
\hline & P29 & $\mathrm{F}$ & 20 & Undergraduate & Urdu/English \\
\hline & P30 & $\mathrm{F}$ & 20 & Undergraduate & English \\
\hline
\end{tabular}




\begin{tabular}{|c|c|c|c|c|c|}
\hline Univ. & Participant & Gender & Age & Education Level & Language of Interview \\
\hline \multirow{15}{*}{ 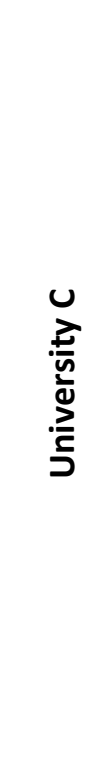 } & P31 & $\mathrm{F}$ & 21 & Post-graduate & Urdu \\
\hline & P32 & $\mathrm{F}$ & 22 & Post-graduate & Urdu/English \\
\hline & P33 & $\mathrm{F}$ & 22 & Post-graduate & Urdu/English \\
\hline & P34 & $M$ & 20 & Undergraduate & Urdu \\
\hline & P35 & $\mathrm{F}$ & 19 & Undergraduate & Punjabi/Urdu \\
\hline & P36 & $\mathrm{F}$ & 21 & Undergraduate & Urdu \\
\hline & P37 & $M$ & 21 & Undergraduate & Urdu \\
\hline & P38 & M & 19 & Undergraduate & Urdu \\
\hline & P39 & M & 21 & Undergraduate & Urdu/English \\
\hline & P40 & $\mathrm{F}$ & 19 & Undergraduate & Urdu/English \\
\hline & P41 & M & 19 & Undergraduate & English \\
\hline & P42 & $\mathrm{F}$ & 19 & Undergraduate & Urdu/English \\
\hline & P43 & $\mathrm{F}$ & 20 & Undergraduate & Urdu \\
\hline & P44 & $M$ & 22 & Undergraduate & Urdu/English \\
\hline & P45 & $M$ & 22 & Undergraduate & Urdu/English \\
\hline \multirow{15}{*}{ } & P46 & M & 18 & Undergraduate & English \\
\hline & P47 & M & 22 & Undergraduate & Urdu/English \\
\hline & P48 & $\mathrm{F}$ & 21 & Undergraduate & English \\
\hline & P49 & $M$ & 18 & Undergraduate & Urdu \\
\hline & P50 & $M$ & 19 & Undergraduate & Urdu \\
\hline & P51 & $M$ & 18 & Undergraduate & Urdu \\
\hline & P52 & $F$ & 20 & Undergraduate & Urdu \\
\hline & P53 & $F$ & 22 & Undergraduate & Urdu/English \\
\hline & P54 & M & 21 & Undergraduate & Urdu \\
\hline & P55 & M & 21 & Undergraduate & Urdu \\
\hline & P56 & M & 22 & Undergraduate & Urdu/English \\
\hline & P57 & M & 18 & Undergraduate & English \\
\hline & P58 & $M$ & 20 & Undergraduate & Urdu \\
\hline & P59 & $M$ & 19 & Undergraduate & Urdu/English \\
\hline & P60 & $M$ & 19 & Undergraduate & Urdu \\
\hline
\end{tabular}

\subsection{Interviews}

We conducted 20-25 minutes long interviews with each participant. We had several questions pre-structured; however, we kept on adding other questions based on the participants' responses. The pre-structured questions revolved around the participants' ability to speak Punjabi, the general linguistic milieu of their households, the perceptions of other people towards Punjabi speakers, and others. The interview tool helps understand the meaning-making process of the participants regarding the 
Punjabi language (Polkinghorne, 1989). We audio-recorded all the interviews and transcribed them for analysis purposes.

\subsection{Recordings}

Recordings of natural conversations were also collected from different Punjabi households. By natural conversation, we mean that some of the authors went to the Punjabi households and recorded the conversation among the family members with their permission. We recorded the conversations to improve the reliability of the data as well as to have an in-depth understanding of the phenomenon. Besides, it was made sure by asking them to speak Punjabi, and the authors also spoke Punjabi with them to make it easier for the researchers to observe the patterns of code-mixing and switching. The total duration of the recordings was 5 hours.

\subsection{Data analysis}

Analysis of interviews and recordings was done through coding with the help of Constructivist grounded theory (Charmaz, 2014). Codes create a "skeleton" (Charmaz, 2006, p. 47) of qualitative data. We assigned different codes to the transcribed data collected through interviews and recordings. Codes were words or phrases to represent the main idea in each line of the data. We coded each line of the data including interviews and recorded speech of the participants (Saldana, 2010). The data were coded inductively. Codes are the smallest units of analysis that capture interesting features of the data (potentially) relevant to the research question. We coded the data in a group instead of each individual working on it separately and assigned those codes on which we agreed. "Codes are the building blocks for themes, (larger) patterns of meaning, underpinned by a central organizing concept - a shared core idea" (Clarke \& Braun, 2017, p. 297). We selected the important codes based on their recurrent occurrence in the data, our theoretical framework and literature review. We selected those important codes that occurred at least in $60 \%$ of the participants' interview. We arranged these codes into categories based on their similarities and interrelatedness. A category is the most represented word or phrase that is used for the representation of a group of similar codes (Charmaz, 2014). We developed emerging categories into themes and findings inductively while relying on data mostly; the themes are discussed below. We also quoted from the data as evidence for elaboration of themes. 


\section{Findings}

This part of the paper is divided thematically per the themes that emerged from the data using Constructivist Grounded Theory as shown in Figure 1.

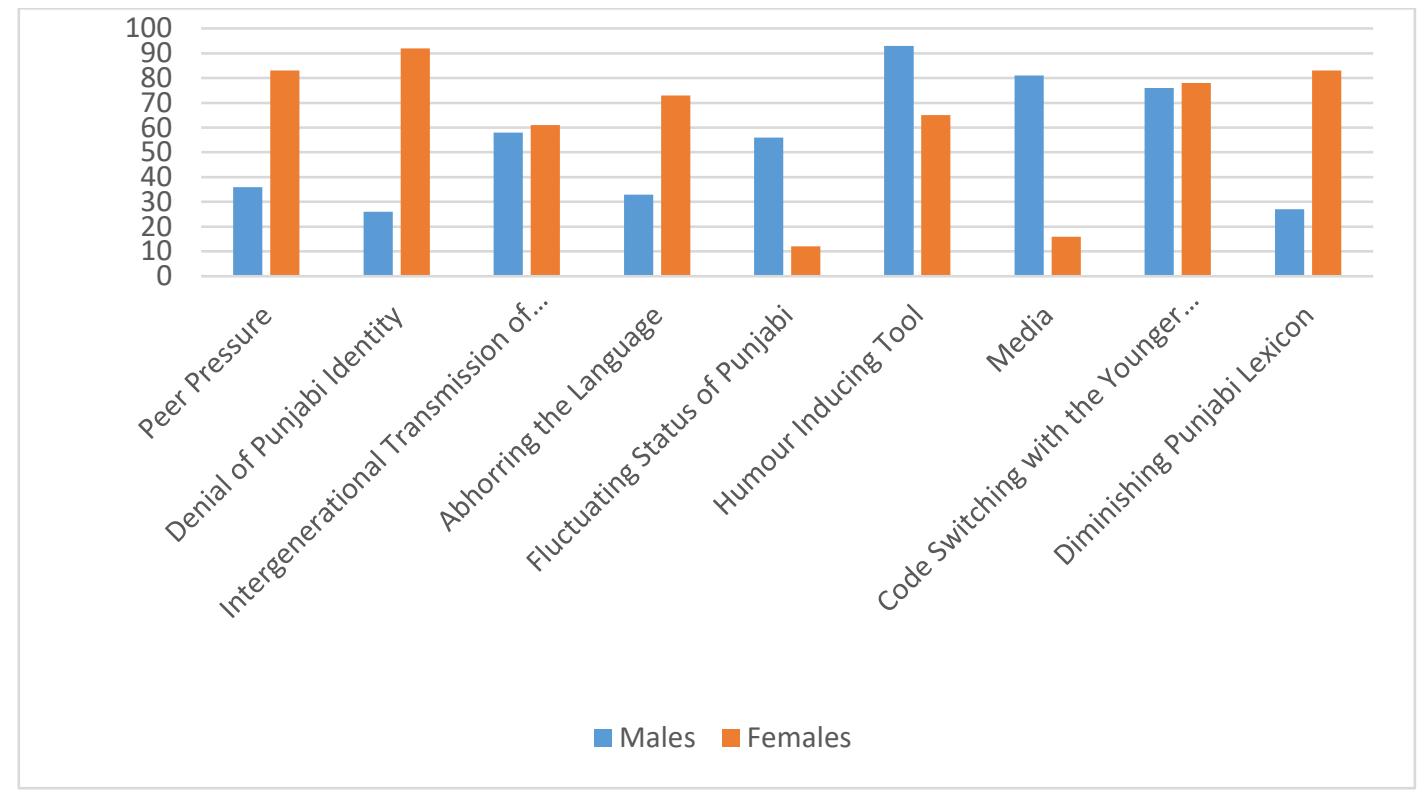

Figure 1: Percentage of the Males/Females contributing to individual themes

\subsection{Peer pressure}

The pressure of conforming to the values of one's social circle is a major driving force for teenagers' recurring behavioral patterns (Brown, 1982; Cheng \& Warren, 2005). Scholars have established that peer pressure strongly affects the workings of language (Cheng \& Warren, 2005; Cohen \& Norst, 1989; Lefkowitz \& Hedgcock, 2002; Walqui, 2000; Woodrow, 2006). In our educational institutions, where different classes and cultures clash, students get influenced by those who are considered superior. Abandoning a mother tongue as a result of peer pressure is also a common observation in such circumstances. The youngsters use stereotypical lens provided by society to look at these issues. One of the male participants narrated such an incident:

I was talking on the phone once in Punjabi and my friends, especially girls, they made fun of me (P28 (M). Interview on March 5, 2019. Translated from Urdu).

The sensitivity of women to the language of power is usually higher than that of men (Pavlenko, 2001). They are more inclined to switch to the dominant language and get rid of the stigma attached to the dominated language (Holmes, 1993; Kisselev, Brown \& Brown, 2010; Pavlenko, 2001). 
You can't speak Punjabi among your friends because if you do, you know you'd be made fun of (P54 (M). Interview on March 14, 2019. Translated from Urdu).

Shaming of the use of indigenous languages is a threat to these languages, which ultimately leads to language shift and language death (Coronel-Molina, 1999; Liyanage \& Canagarajah, 2019; McCarty, Romero-Little, \& Zepeda, 2006). Women are usually custodians of the local language(s) for being less exposed to a foreign or second language as they often keep the indigenous language, but once they adopt the dominant language the language shift becomes inevitable (Constantinidou, 1994; Mascarenhas-Keyes, 1994; McDonald, 1994; Pavlenko, 2001). We observed that girls were more resistant to the Punjabi language and even to their Punjabi identity. Below is one of the most common answers of our participants when asked about their perception of a Punjabi speaker.

Look at him/her, such an illiterate (paendo) (P52(F). Interview on March 14, 2019.

Translated from Urdu).

Such responses show that the lack of prestige and stereotypical views attached to the Punjabi language have been driving the Punjabis away from it. The term "paendo" (illiterate often linked with crude manners) is consistent with the societal patterns which ideologically operate to stigmatize the language and the respective linguistic group (Coronel-Molina, 1999; McCarty, Romero-Little, \& Zepeda, 2006). The linguicism (Phillipson \& Skutnabb, 1995) against this language affects younger generations of Punjabi speakers as they associate their language with illiteracy and mediocrity because of societal behaviors. According to Bourdieu (1991), the education system uses certain types of language(s) and students are disciplined accordingly (Schubert, 2014). In this example, education system legitimizes Urdu and English and does not include other languages, which makes Punjabi unacceptable.

Although Punjabi speakers are dominant numerically in Pakistan and they have more power in the country, their language has been marginalized by English and Urdu. Bourdieu (1991) considers such a situation as symbolic violence since speakers now avoid using their mother tongue in the presence of their peers. Thus, linguistic resources (Blommaert, 2010) of the speakers of Punjabi are not only valueless but rather a cause of shame for them. This phenomenon is usually found with indigenous minority language speakers (Coronel-Molina, 1999; McCarty, Romero-Little, \& Zepeda, 2006) but is rare with the majority language speakers as in the case of Punjabi.

\subsection{The self-denial of Punjabi identity}

From our literature review and interaction with several Punjabis, we have observed that Punjabis themselves are responsible for the downfall of their language as they feel ashamed to own it. The Punjabis associate themselves with languages that give them social and 
economical benefits. They consider themselves a part of the "imagined community" (Anderson, 2006; Kanno \& Norton, 2003) of the self-proclaimed sophisticated elites of the country who mostly speak Urdu and English. These include civil and military bureaucracy and professionals in the country (Qadeer, 2006). They degrade the Punjabi language by calling it a language of illiterates, although the Punjabi language boasts rich heritage and literature. Likewise, the study participants and general public link the Punjabi language with illiteracy. A recurring phrase that we heard from many people, especially females, during the interviews, was "I am not Punjabi, my parents are" (P15(F). Interview on February 26, 2019. Translated from Urdu). Besides, some of the participants indicated a lack of emotional attachment to the language, and feel rather proud of their disassociation with it.

I don't feel a sense of belonging to the language as I have never spoken it (P59(M). Interview on March 14, 2019. Translated from Urdu.)

It has been becoming a trend that people feel proud of saying that they are not Punjabi because this language is insulting in nature (P9(M). Interview on February 26, 2019. Translated from Punjabi).

It's not always that Punjabis deny their identity altogether, but when it comes to the language, it's a completely different story (P52(F). Interview on March 14, 2019. Translated from Urdu).

The above responses suggest that the Punjabi language has been marginalized by the Punjabis themselves. To associate themselves with the elites of the society, Punjabis have renounced their own linguistic identity. As already stated, the denial of linguistic identity has also been found in indigenous language speakers in other studies (CoronelMolina, 1999; Liyanage \& Canagarajah, 2019; McCarty, Romero-Little, \& Zepeda, 2006). Interestingly, such denial of Punjabi identity is happening only in the terms of a language while in cultural and social aspects Punjabi people feel proud of their identity.

Although politically and numerically dominant, Punjabi speakers adopt the statesupported minority languages, which are Urdu and English. This is happening due to the linguistic policy of the state and language ideology as, over the years, Pakistani state policy has promoted Urdu as the national language, and to some extent, English as the official language (Rahman, 1997). Moreover, the education system also plays an important role by neglecting native languages of the Pakistani population (Manan \& David, 2013; Manan, David, \& Dumanig, 2015).

\subsection{Intergenerational transmission of stereotypes}

Intergenerational transmission of the Punjabi language is diminishing because of parents' attitude towards the language as foul. As discussed in the literature review section, Punjabi was systematically reduced to a stigmatized status. The stereotypical 
views regarding Punjabi are still been passed on to generation after generation. For instance, a few of the participants said the following.

Our parents never converse with us [in Punjabi], rather they consider talking in Punjabi as ill-mannered (P59(M). Interview on March 14, 2019. Translated from Urdu).

Yes, sometimes we talk in Punjabi but only with our mother. Our father does not allow Punjabi at home (P2(M). Interview on February 26, 2019. Translated from Urdu).

My father is usually concerned about people's remarks if we speak in Punjabi. He always asks us to talk in Urdu even with our mother, but my mother again switches back to Punjabi (P2(M). Interview on February 26, 2019. Translated from Urdu).

Participants' responses highlight how Punjabi parents are driving younger generations away from the language that provides the ethnic base for their identities. The implications of this act are clear. Due to almost no exposure to the Punjabi language, people from younger generations eventually move away from the language. Few other instances of the current theme are as follows.

It is not delivered to us, they (parents) speak Punjabi [among themselves or with other elderly people] (P23(M). Interview on March 5, 2019. Translated from Urdu).

Our parents only converse in Punjabi among themselves and not with us (P33(F). Interview on March 5, 2019. Translated from Urdu).

I remember when I was young and tried to speak Punjabi at home, my parents' immediate response would be, 'where did you learn that word?' And then they would tell me how it was not 'nice' (air quotes). I think that's where it started and that's why I never feel comfortable speaking the language (P38(M). Interview on March 5, 2019. Translated from Urdu).

Growing up, our parents always focused on teaching us Urdu and English and Punjabi went somewhere in the background (P4(M). Interview on February 26, 2019. Translated from Punjabi).

Therefore, it is apparent that the process of abandoning the Punjabi language operates at the family level. The family unit proves to be the substructure that triggers degradation processes of Punjabi by glorifying languages of relatively minor groups, such as English and Urdu² (Rahman, 1997), and stigmatizing their language. Contrary to this, speakers of other local languages such as Pashtu, Sindhi, Balochi, and others, pass their languages to next generations (Rahman, 1997).

\footnotetext{
${ }^{2}$ Urdu is the first language of $8 \%$ population and English is spoken by $1-2 \%$ elites of the country.
} 


\subsection{Abhorring the language}

As concluded in the previous section, it is obvious that Punjabi speakers do not pass on their language to younger generations in the family. The process of abandoning Punjabi does not stop at the family level, rather it keeps on forming the communal psyche of Punjabi people. Similar to these participants, other people also continue to instill these notions of inferiority of Punjabi language into their compatriots' minds as well, thus leading to the attachment of shame with Punjabi. The notions instilled by parents and society lead to the point where Punjabis are humiliating the other Punjabis for speaking their ethnic language.

On one hand, some participants have supported the idea that Punjabi is not abhorred as a language.

Some people think it is such a sweet language and they would encourage you to talk in Punjabi (P32(F). Interview on March 5, 2019. Said in English).

I always love to communicate in Punjabi with my fellow Punjabis (P29(F). Interview on March 5, 2019. Said in English).

However, many of the participants responded in affirmation.

Punjabi himself degrades the other Punjabi (P20(F). Interview on March 5, 2019. Translated from Urdu).

Society does not consider it [a] good [language] (P22(F). Interview on March 5, 2019. Translated from Urdu).

If we are sitting in a gathering and someone starts to speak in Punjabi, for sure, he will be made fun of in front of the whole group which might ironically be of all Punjabis (P14(M). Interview on February 26, 2019. Translated from Punjabi).

The participants' responses show the way the language is being degraded at the social level and not merely at the family level as discussed in relation to the theme in the previous section. Punjabi also faces negligence by governmental authorities, which adds to its stigmatization by the public (Mansoor, 2004). Therefore, Punjabi is facing intellectual as well as cultural degradation, which is one important component of language death and language shift (Skutnabb-Kangas, 1999). As mentioned above, the communal psyche comes into play here.

The reason Punjabis and Punjabi language are degraded is that Punjabis themselves never bother to defend their language. For Pathans, it is their identity and they're proud of it. This is why you don't see them being made fun of because of their language. And even if someone does that, they shut him down. Punjabis don't retaliate or defend their language and that's why they are easy targets of such bullying (P32(F). Interview on March 5, 2019. Said in English). 
Yet at another level, the predicament of Punjabi is the result of Punjabi's relation to English and Urdu. English and Urdu, being made the languages of power and knowledge, are defining the fate of other languages, be it Punjabi, Balochi, Pashto, Sindhi, or any other regional language in Pakistan. Unlike Punjabi speakers, other regional languages are being fortified by their speakers. For example, in the case of the Sindhi language, it is being promoted and taught at the institutional level as a compulsory subject (Rahman, 1996). The symbolic value (Bourdieu, 1991) of English and Urdu can only be defined when in relation to other languages. As for Punjabi, it is not comparable (being institutionally denigrated), and that seems to be the source of its predicament in a particular linguistic context, such as Pakistani society.

\subsection{Status of Punjabi in relation to geographical location}

Interestingly, the value of the Punjabi language changes according to the change in geographical location. In some areas of Pakistan, according to participants' view, Punjabi is not treated as the language of lower domains of use as compared to the capital city where there are speakers from different languages, although Punjabi outnumbers the speakers of other languages in Islamabad, too. In cities with the Punjabi majority, the case is different.

We do not speak Punjabi at home, but whenever we visit our village we do speak in Punjabi with elder relatives (P2(M). Interview on February 26, 2019. Translated from Urdu).

When asked about the reason for this change of behavior, the participants responded in the following manner.

Because we are located in the Capital Territory (P48(F). Interview on March 14, 2019. Said in English).

I do not [feel comfortable] speak[ing] Punjabi in Islamabad. Yeah, I speak Punjabi whenever I visit Faisalabad (P32(F). Interview on March 5, 2019. Translated from Urdu).

In Lahore, even the officers with the highest ranks speak Punjabi (P3(M). Interview on March 20, 2019. Translated from Punjabi).

The responses subtly refer to the changing symbolic value of Punjabi based on localities. According to the participants, the same person who refuses to use Punjabi in Islamabad declares himself bold enough to use it in other cities, such as Faisalabad, Lahore, or village areas.

Besides, there were responses according to which Punjabi maintains its status in every geographical context. 
I don't think anything could ever affect the value of this language in my eyes. If I ever meet a Punjabi in any part of the country, I will greet him in my mother tongue (P18(M). Interview on March 1, 2019. Translated from Urdu).

However, such responses were overruled by the majority of responses that argued otherwise.

I believe you would have heard that a certain renowned school issued an official notification banning the Punjabi language on its premises. Now that's the kind of institutionalized hatred Punjabis are facing, and it is even ingrained in our kids from a very young age (P46(M). Interview on March 5, 2019. Said in English).

The theme about the importance of Punjabi depending on geographical location is particularly important concerning the current study because it limits the degradation of Punjabi within the geographical boundary of Islamabad. Therefore, it means that educated people and people in power are leaving Punjabi. It is rather becoming the language suitable in rural areas for everyday conversation, henceforth, it is considered a low-scale language used in limited circles (Blommaert, 2010). However, when the language speakers go out of that circle, they consider that language a stigma. As a result, the language is losing its value and its symbolic power (Bourdieu, 1991).

\subsection{Humor inducing tool}

When asked about the usage of Punjabi in their daily discourse, participants spontaneously replied with the following statements.

Punjabi is used only to pull off a joke (P40(F). Interview on March 5, 2019. Translated from Urdu).

Something funny sounds even funnier in Punjabi (P11(M). Interview on March 1, 2019. Translated from Urdu).

Similarly, when asked whether they speak Punjabi in their daily conversations, several participants responded with,

Occasionally, we speak in Punjabi to make a joke (P50(M). Interview on March 14, 2019. Translated from Urdu).

The association of humor with Punjabi is seen as an inevitable connection. As seen previously, the value of Punjabi fluctuates from geographical territory to territory, its value also fluctuates depending on the context of use. Where in one context, Punjabi is preferred, it is avoided in another context of use. For instance, Punjabi enjoys sound status when used in informal domains such as humor. Whereas the more formal the setting, the less there is the use of Punjabi. Therefore, the Punjabi language is seen as getting compartmentalized to the domains of informal use only. Similar to the situation 
described by Bourdieu (1991), as stated by the participants, this compartmentalization can eventually lead to the ultimate abandonment of the language by its speakers. Although Punjabi, being the dominant language, is very rich in literature in Pakistan and specifically in India, people apparently link it with humorous situations only. Compartmentalizing language to certain domains of use, especially avoiding its use for serious matters is one of the factors for language death (Reagan, 2019).

\subsection{Language use in media}

According to participants, media appear to be the reason for compartmentalization of Punjabi to informal domains of use. Time allocated to the Punjabi language on television is strategically divided between comedy shows, such as Khabar $\mathrm{Naak}^{3}$, Mazaaq Raat ${ }^{4}$, Hasb-e-Haal ${ }^{5}$, and others. Interestingly, in those shows, the host is usually disseminating intellectual thoughts in Urdu and occasionally in English, whereas sarcastic or humorous comments are always in Punjabi.

Punjabi is usually used in theatre (P3(M). Interview on February 26, 2019. Translated from Urdu).

You can see comedy shows even, what they talk about, and it is specifically in Punjabi (P7(M). Interview on February 26, 2019. Translated from Urdu).

We all know that different media channels always serve an agenda. In the case of Punjabi, the objective is to taint the image of the language by using it in vulgar discussions and stage shows etc (P57(M). Interview on March 14, 2019. Said in English).

The participants' responses also reflect the same reality about the media's role. Therefore, the notion of Punjabi as the language of pun and humor is held up in society through media. In such a way, the language is not only reduced to informal use but its status is sustained. Henceforth, the language is not considered valuable to be used for serious discussions. It is rather made suitable for lighter discussions.

The themes introduced in the following section are based on the observation of natural recordings of conversations from Punjabi households.

\footnotetext{
${ }^{3}$ A satirical comedy show that is aired on one of the well-known news channels of Pakistan, Geo News. The show provides a satire on the political situation of the country.

${ }^{4}$ A similar show that gets aired on Dunya News.

${ }^{5}$ It is a comedy show that provides satire on the political situation of Pakistan. It is also aired on Dunya News.
} 


\subsection{Code-switching with the younger generation}

Code-switching patterns were observed in the recordings of natural conversations from Punjabi households. It was observed that parents or elderly people frequently shifted the code to English or Urdu when talking to their children. One such incident is given below when the same person, who was worried about Punjabi's predicament, shifted from Punjabi to Urdu to talk to his son. He was talking in Punjabi to address his uncle.

'Uncle, there is a report of UNESCO that Punjabi will not be used in any household by the year 2030' (S16(M). Observation on April 13, 2019. Translated from Punjabi).

No household permits the use of Punjabi with kids (S16(M). Observation on April 13, 2019. Translated from Punjabi).

I had a course on Punjabi in my BS degree program (S16(M). Observation on April 13, 2019. Translated from Punjabi).

A few moments later, he switched to Urdu to address his son.

'(Child's name), come here. See what I have got. Drink this juice and place the glass on the table' (S16(M). Observation on April 13, 2019. Translated from Urdu).

The same individual who was fluently talking in Punjabi switched his code to Urdu when he had to address his child. Ironically, he was referring to the predicament of Punjabi at the hands of Punjabis themselves and he did the same thing subconsciously when it came to his situation. This also shows that parents avoid speaking Punjabi with children as they consider that it has a low market value (Bourdieu, 1991) and therefore they communicate in Urdu or English to develop the socially valued linguistic resources of their children (Blommeart, 2010). Henceforth, the case of Punjabi can be an interesting example of code-switching that leads to language change between generations (Backus, 2005). This theme strengthens the views of participants discussed above (see Intergenerational Transmission of Stereotypes). These code-switching patterns become the main cause of the gradual decrease in the usage of Punjabi by younger generations leading to the eventual death of language. As discussed by (Gillani \& Mahmood, 2014; Romaine 1995) earlier research, our paper also highlights the diminishing use of the Punjabi language with the younger generation. As the language is not getting transmitted to the next generations, this situation is contributing to a gradual abandonment of the Punjabi language. Therefore, a gradual pattern of abandonment of the language is clear in the analysis, which will further get strengthened if the Punjabis do not start transmitting the language to their younger generations. 


\subsection{Diminishing Punjabi lexicon}

Through the recordings and our general observations, we also noted that some words have become extinct in the Punjabi lexicon and were replaced by English or Urdu words (Backus, 2005). The list of such words is given below in Table-3. The intrusion is so subtle and subconscious that the users of language do not even recognize it as an intrusion. This intrusion of dominant languages into the linguistic scape of dominated languages might cause the dominated language to be replaced eventually. Similarly, the intrusion of Urdu and English causes the Punjabi lexicon to shrink and transform into the lexicon of Urdu and English, thus proving to be another cause behind the gradual shift of the language. The death of the language is subject to the gradual replacement of the Punjabi lexicon with the Lexicon of dominant languages. This conclusion supports the argument of the paper by further highlighting how the languages of relatively minor usage are influencing the lexicon of Punjabi.

Table 3: Words of Punjabi replaced by Urdu and English

\begin{tabular}{|c|c|c|c|}
\hline Punjabi Equivalent & English replacement & Punjabi Equivalent & Urdu replacement \\
\hline Aئ (cholah-backpack) & bag & (kلَsurri-girl) & لرُكى (larki-girl) \\
\hline (ن:manno-accept) & accept & (ئك⿶凵ه(vekh-look) & ليكبكهل (dekh-look) \\
\hline Har(chinta-tension) & tension & (بدال(jiddaan-for example) & بيسيسا(jese-for example) \\
\hline (thais-hurt) & hurt & ووجا (duja-second) & (سوس (dusra-second) \\
\hline /of(khura-bathroom) & bathroom & $<-4$ (chatay-hair) & U:(baal-hair) \\
\hline بونugaithak-drawing room) & drawing room & حول(choal-rice) & جְاول(chawal-rice) \\
\hline لحات (Lihaaf-blanket) & blanket & |بو:(bu-a-door) & دروازه \\
\hline
\end{tabular}

\section{Discussion and conclusion}

The Punjabi language has been disappearing from certain domains of use over the past few years (Jalal, 1995; Nazir, Aftab \& Saeed, 2013; Rammah, 2006; Zaidi, 2010) and has now been limited for inducing humor in an otherwise serious conversation. Usually, in bilingual situations, the minority language or the language of the dominated group is facing challenges in which the speakers of language start using languages other than their native one in several domains and reduce the use of native language to few domains (Reagan, 2019). In our case, the Punjabi language is getting limited to the domain of humor and non-serious discussions. This shift is taking place due to official recognition of languages within the national context and non-linguistic factors such as economic opportunity or the lack thereof (García \& Leiva, 2014; Piller, 2016; Simons \& Fennig, 2018). This phenomenon has been quite common and yet neglected because of Punjabis' dissociation with their language. Punjabi's dissociation with their language is 
caused by the influence of English and Urdu. The prestige attached to Urdu and English has successfully led these languages to infiltrate into the lexical territories of Punjabi. Moreover, this indicates the intellectual death of the Punjabi language (Khokhlova, 2014; Jaffrelot, 2002; Shafi, 2013) as it has only been used for very trivial purposes like making jokes or adding a sarcastic comment. It has become a tool of comic relief and people usually blame the media for it. Besides that, according to the participants' views, the stage shows have also played a significant role in side-lining Punjabi and in associating vulgarity and immodesty with it. Participants maintained that this is one of the major reasons that Punjabis feel ashamed of their language and even the ones who do speak it become a victim of peer pressure, mostly at the hands of their fellow Punjabis. However, this reduction of the Punjabi language to be used in a relatively vulgar context by media is a result of ideological and political factors that are at play. For instance, the ideological prestige attached to Urdu and its role in the state-building of Pakistan along with the global prestige of English based on the former predominance of the UK and the present predominance of the United States plays an important role.

Furthermore, the large-scale adoption of Urdu and English expressions in the Punjabi lexicon is also responsible for the downfall of the language. This adoption takes place due to the dominance of prestigious minority languages, Urdu and English, over Punjabi (Khokhlova, 2014). In fact, "in a living community, the (lexical) borrowing is asymmetrical: the [language] flow is mainly from the sociolinguistically dominant language to the other one" (Myers-Scotton, 1992, p. 34). In the case of Punjabi, the horizontally dominant language Punjabi is threatened by vertically dominant languages, such as Urdu and English. "Horizontally distributed languages are (vertically) defined as low-scale languages, local languages or languages used by individuals in the neighbourhood or at home, even if such languages are actually used by millions of people" (Blommaert, 2007, p. 12). The reason is Punjabi speakers' dissociation with the language that is hindering the Punjabi language from evolving further and causing the replacement of the Punjabi lexicon with Urdu and English. This replacement is a result of the speakers' insufficient knowledge of their language and the relatively higher status of English and Urdu (Backus, 2005). Moreover, the attitude of Pakistani society, the fluctuating nature of Punjabi's status, and the patterns of code-switching also contribute to the receding of Punjabi language from the formal contexts of usage. This compartmentalization of Punjabi to a few limited domains of use is leading to its eventual extinction in Pakistan. Moreover, the use of any language is determined by the education policies of the state (Collins, 2012), which, unfortunately, are the least supportive in the case of Punjabi in the Pakistani social context.

One important aspect that emerged during the study is that the females were more reluctant to accept their Punjabi identity. Most females were not even willing to be interviewed to avoid acknowledging their Punjabi identity. As apparent in the analysis, they do not consider Punjabi to be a legitimate language but rather prefer to present themselves as Urdu/English speakers. This situation can be better described as 
symbolic (self) violence (Bourdieu, 1991) as these speakers abhor their ethnic identity and hate to be known as Punjabi. The speakers perceive the dominance of Urdu and English "to be legitimate, and thus think and act in their own best interest" to avoid revealing their ethnic identity (Schubert, 2014, p. 180). Usually, females are considered to be more inclined to native languages thus they are implied to be the preservers of these languages (Constantinidou, 1994; Mascarenhas-Keyes, 1994; McDonald, 1994; Pavlenko, 2001), however, in this study, females are more reluctant to acknowledge their Punjabi identity as explained above. Resultantly, it makes the transmission of the language to the coming generation more difficult as in Pakistan traditionally mother spends more time with the children. Henceforth, the shame felt by females regarding their Punjabi identity further threatens its existence in the future, especially in a multilingual city like Islamabad.

Other regional and local languages have also lost their market value due to the dominance of English and Urdu. Thus, people are turning towards English more and more (Haidar, 2019; Manan \& David, 2013). The speakers of regional languages consider commercially accepted languages necessary for communication in multilingual cities (Haidar, 2016, 2019) and never feel ashamed of using them. They rather feel proud of their newly acquired linguistic identity and consider it a privilege to pass on their newly acquired language to the next generations (Khan, 2018; Rahman, 2010). The main causes of language shift are (i) socioeconomic: with the language losing its value in the market and (ii) socio-political: including language policies and stigmatization (Janse, 2003). However, the situation with Punjabi speakers is alarming and this happens as Punjabi speakers are lost in the love of the new land (Rammah, 2006); that new land appears to be Urdu and English given their market value as compared to Punjabi. Moreover, being a large segment of the population, Punjabis are politically dominant and assertive as opposed to other ethnic groups, but their linguistic and social identity is threatened without them being aware of it.

Generally, during language shift and language death, there is resistance from some of the native speakers who lament the loss of their language(s). However, the case is different when it comes to Punjabi. In the case of Punjabi, the native speakers are ashamed not only of their language but also of their ethnic identity. Ethnic identity plays a crucial role in the revitalization of a language (Janse, 2003), however, in this case, it plays a negative role. We, therefore, argue that Punjabi, although still the language of the majority, faces threats of extinction in the Pakistani context since its speakers have started hating the language. In other domains (cultural, social, political), they usually do not deny their Punjabi identity but in the case of the language they reach the level, "I am not Punjabi my parents are". They even deny their ethnic identity, as Punjabi is not only a linguistic identity but also one of the largest ethnic groups in India and Pakistan. However, this stigmatization of Punjabi identity is not prevalent in Indian Punjab. Thus, it can be concluded that the situation is rather of language shift in Pakistan only since the positive attitude of Indians towards Punjabi cannot lead to the 
language death of the Punjabi language. This is an interesting sociolinguistic phenomenon where due to the negligence of state policies, education system, language ideology, and linguistic injustice (García \& Leiva, 2014; Piller, 2016), the language of the dominant majority has lost its old dominant status. Punjabi in Pakistan is linked with Sikh identity while Urdu is presented as an Islamic language and thus people also disown Punjabi on religious grounds.

Therefore, we argue that along with other factors, speakers' consciousness plays an important role in the maintenance and survival of a language. This aspect is usually ignored by Bourdieu's (1991) theory, the theory of linguicism by Phillipson \& Skutnabb (1995), and Blommaert's (2010) sociolinguistics of globalization. Unlike other dominated languages, which are always in minority due to socio-economic pressure, colonialism, and globalization, the Punjabi ethnic group is a dominant majority group of Pakistani society. However, Punjabi speakers are overwhelmed with the idea of the new nation, new identity, and new language so much that they have ignored their language and ultimately their identity. This study, henceforth, contributes a new aspect, e.g., that the speakers' sensitivity about the threat to their identity and language can also play an important role in the survival of a language as is happening in the case of other regional languages of Pakistan. We can conclude that it is not only power but consciousness is also required for the survival of a language. Another such example is the conscious switch to Hebrew, a dead language for about 2000 years, in the first half of $20^{\text {th }}$ century. It was done by Jewish speakers of Yiddish, Ladino, and other languages used by the Jewish community, with religion (Judaism) as a powerful driving force (Ben-Rafael, 1994). Moreover, the lack of threat to their dominance also plays an important role in diminishing the prestige of the Punjabi language. Other language speakers in Pakistan often feel threatened due to the political and social dominance of Punjabis in the country. This makes them sensitive to resist the dominance of Punjabis and of Urdu language. This helps the survival of their languages as they usually feel proud of their linguistic identity. Thus, the social attitudes of the speakers also play important role in the symbolic power or degradation of a language along with its social and economic status (Bourdieu, 1991).

Moreover, language ideology, especially religious sentiments also play a role in the degradation of Punjabi by associating Punjabi with Sikh identity and Urdu with Islamic identity (Abbas, Chohan, Ahmed \& Kaleem, 2016; Murphy, 2018). However, this is not happening in the case of the English language due to the material and symbolic benefits attached to it. English was one of the most hated languages by Muslims due to British colonization in India (Rahman, 2005). The attitude towards English is still differing among people, but the educated youngsters have accepted it and feel safer to identify themselves with English rather than with Punjabi. Therefore, religious sentiments which play a negative role against Punjabi (Javid \& Martin, 2020) do not affect students' perception of the prestige of the English language. This can be interpreted in the 
following way, e.g., that the material and symbolic benefits attached to English surpass religious sentiments that play a negative role in the case of the Punjabi language.

The study thus adds to Bourdieu's (1991) theory of symbolic power of language that the dominance of language depends not only on the dominance of its speakers but also on their attitude towards their language. Punjabi speakers are in majority and are also dominant in Pakistan therefore the situation is described as a majority language death (Khokhlova, 2014). They ignore their language for not feeling any threat to their political dominance or identity, but they are losing their identity. In this regard, the state and global scenario also play an important role. In the Pakistani context, the language ideology, religious beliefs, and state policies (Blommaert, 2014) also play a crucial role in undermining the Punjabi language. It is described as linguicism that refers to "ideologies, structures and practices which are used to legitimate, effectuate and reproduce an unequal division of power and resources (both material and immaterial) between groups which are defined based on language" (Skutnabb-Kangas 1988, p. 13). Due to the interest of the elite class, the language beliefs and ideology do not play a negative role in the case of English as it represents the colonial era and Western dominance. This shows that speakers of the English language "have more power and material resources than their numbers would justify, simply because of being speakers of those languages and varieties" (Skutnabb-Kangas, 1999, p. 60). Building upon the insights of Blommaert, the paper concludes that the vertically dominant languages, English and Urdu, due to globalization and language ideology, have made the horizontally dominant language valueless.

The study adds to the theory of linguicide as it is argued that the minority language or the language of the dominated group is usually at risk of survival. However, in the case of Punjabi, the language of the dominant majority is threatened due to the negligence of its native speakers. The research in the field of language death and language shift usually claims that "majority languages expand at the expense of minority languages" (Skutnabb-Kangas, 1999, p. 60). The speakers of other regional and local languages in Pakistan also use English and Urdu for education and formal purposes but they switch to their mother tongue while speaking with the same language group. Moreover, parents usually transfer their language to the young generation while speaking that language with their children. However, even though the Punjabi parents speak Punjabi with each other, they switch to Urdu or English while speaking to their children. Henceforth, the youngsters are right in saying that their parents are Punjabi while they are not, as they feel ashamed of their linguistic identity. 


\section{References}

Abbas, F., Chohan, M. N., Ahmed, M., \& Kaleem, M. (2016). Punjabi language in Pakistan: past, present and future. Hamdard Islamicus, 39(3\&4), 1-14.

Abley, M. (2003). Spoken here. Travels among threatened languages. Toronto, ON: Random House of Canada.

Anderson, B. (2006). Imagined communities: Reflections on the origin and spread of nationalism. London: Verso books.

Backus, A. (2005). Codeswitching and language change: One thing leads to another? International Journal of Bilingualism, 9(3-4), 307-340.

Ben-Rafael, E. (1994). Language, identity and social division: The case of Israel. Oxford: Oxford University Press.

Blommaert, J. (2007). Sociolinguistic scales. Intercultural Pragmatics, 4(1), 1-19.

Blommaert, J. (2010). The Sociolinguistics of Globalization. Cambridge: Cambridge University Press.

Blommaert, J. (2014). State ideology and language in Tanzania. Edinburgh: Edinburgh University Press.

Bourdieu, P. (1991). Language and Symbolic Power (trans. G. Raymond \& M. Adamson). Cambridge, MA: Harvard University Press.

Brown, B. B. (1982). The extent and effects of peer pressure among high school students: A retrospective analysis. Journal of Youth and Adolescence, 11(2), 121-133.

Charmaz, K. (2006). Constructing grounded theory: A practical guide through qualitative analysis. US: Sage.

Charmaz, K. (2014). Constructing grounded theory. US: Sage.

Cheng, W., \& Warren, M. (2005). Peer assessment of language proficiency. Language Testing, 22(1), 93-121.

Clarke, V. \& Braun, V. (2017) Thematic analysis. The Journal of Positive Psychology, 12 (3), 297298, DOI: 10.1080/17439760.2016.1262613

Cohen, Y., \& Norst, M. J. (1989). Fear, dependence and loss of self-esteem: Affective barriers in second language learning among adults. RELC Journal, 20(2), 61-77.

Collins, J. (2012). Migration, sociolinguistic scale, and educational reproduction. Anthropology \& Education Quarterly, 43(2), 192-213.

Constantinidou, E. (1994). The "death" of East Sutherland Gaelic: Death by women? In P. Burton, K. Dyson \& S. Ardener (Eds.), Bilingual women. Anthropological approaches to second-language use (pp.111-127). Oxford/Providence: Berg.

Coronel-Molina, S. M. (1999). Functional domains of the Quechua language in Peru: Issues of status planning. International Journal of Bilingual Education and Bilingualism, 2, 166-180. https://doi.org/10.1080/13670059908667687

Creswell, J. (2012). Qualitative Inquiry and Research Design: Choosing among Five Approaches. London: Sage.

Crystal, D. (2000). Language death. Cambridge, UK: Cambridge University Press. 
Dalby, A. (2003). Language in danger. How language loss threatens our future. Harmondsworth, UK: Penguin.

Dewey, J. (2007). Essays in experimental logics. New York: Dover Publications.

Din, M., \& Ghani, M. (2017). A sociolinguistic study on the diminishing features of the Punjabi lexicon. International Journal of English Linguistics, 7(3), 152-160.

García, O. \& Leiva, C. (2014). Theorizing and enacting translanguaging for social justice. In Heteroglossia as practice and pedagogy (pp. 199-216). Dordrecht: Springer.

Gibbs, W. (2002). Saving dying languages. Scientific American, 287, 78-86.

Gillani, M., \& Mahmood, M. A. (2014). Punjabi: A tolerated language, young generations' attitude. Research on Humanities and Social Sciences, 4(5), 129-137.

Fishman, J. A. (1991). Reversing language shift: Theoretical and empirical foundations of assistance to threatened languages (Vol. 76). Bristol, UK: Multilingual Matters.

Haidar, S. (2016). Passport to privilege: access to English in different school systems in Pakistan. University of Rochester.

Haidar, S. (2019). The role of English in developing countries: English is a passport to privilege and needed for survival in Pakistan. English Today, 35(3), 42-48.

Holmes, J. (1993). Immigrant women and language maintenance in Australia and New Zealand. International Journal of Applied Linguistics, 3, 159-179.

Jaffrelot, C. (Ed.). (2002). A History of Pakistan and its Origins. Cambridge: Anthem Press.

Jalal, A. (1995). Conjuring Pakistan: History as official imagining. International Journal of Middle East Studies, 27(1), 73-89.

Janse, M. (2003). Language death and language maintenance: Problems and prospects. In Language Death and Language Maintenance: Theoretical, practical and descriptive approaches (pp. 9-17). Amsterdam: John Benjamins.

Javid, H., \& Martin, N. (2020). Democracy and discrimination: Comparing caste-based politics in Indian and Pakistani Punjab. South Asia: Journal of South Asian Studies, 43(1), 136-151.

Kanno, Y., \& Norton, B. (2003). Imagined communities and educational possibilities: Introduction. Journal of language, identity, and education, 2(4), 241-249.

Khan, A. (2018). Wither mother-tongue (in) education? An ethnographic study of language policy in rural primary schools in Pakistan. In J. Crandall \& K. Bailey (Eds.), Global perspectives on language education policies. (pp. 23-33). New York, NY: Routledge.

Khokhlova, L. V. (2014). Majority language death. In H. C. Cardoso (Ed.), Language Endangerment and Preservation in South Asia. Hawaii, US: University of Hawai'i Press.

Kisselev, P., Brown, M. A., \& Brown, J. D. (2010). Gender differences in language acculturation predict marital satisfaction: A dyadic analysis of Russian-speaking immigrant couples in the United States. Journal of Comparative Family Studies, 41(5), 767-782.

Lefkowitz, N., \& Hedgcock, J. (2002). Sound barriers: Influences of social prestige, peer pressure and teacher (dis)approval on FL oral performance. Language Teaching Research, 6(3), 223244.

Liyanage, I., \& Canagarajah, S. (2019). Shame in English language teaching: Desirable pedagogical possibilities for Kiribati in Neoliberal Times. TESOL Quarterly, 53(2), 430-455. 
Manan, S. A., \& David, M. K. (2013). Mapping ecology of literacies in educational setting: The case of local mother tongues Vis-à-Vis Urdu and English languages in Pakistan. Language and Education, 28(3), 203-222.

Manan, S. A., David, M. K., \& Dumanig, F. P. (2015). Disjunction between language policy and children's sociocultural ecology-an analysis of English-medium education policy in Pakistan. Language and Education, 29(5), 453-473.

Mansoor, S. (2004). The status and role of regional languages in higher education in Pakistan. Journal of Multilingual and Multicultural Development, 25(4), 333-353.

Mascarenhas-Keyes, S. (1994). Language and diaspora: The use of Portuguese, English and Konkani by Catholic Goan women. In P. Burton, K. Dyson \& S. Ardener (Eds.), Bilingual women. Anthropological approaches to second-language use (pp.149-166). Oxford/Providence: Berg.

McCarty, T. L., Romero-Little, M. E., \& Zepeda, O. (2006). Native American youth discourses on language shift and retention: Ideological cross-currents and their implications for language planning. International Journal of Bilingual Education and Bilingualism, 9(5), 659-677.

McDonald, M. (1994). Women and linguistic innovation in Brittany. In P. Burton, K. Dyson \& S. Ardener (Eds.), Bilingual women. Anthropological approaches to second-language use (pp. 85-110). Oxford/Providence: Berg.

Murphy, A. (2018). Writing Punjabi across borders. South Asian history and culture, 9(1), 68-91.

Myers-Scotton, C. (1992). Codeswitching as a mechanism of deep borrowing, language shift, and language death. In M Brenzinger (ed.), Language death: Factual and theoretical exploration with special reference to East Africa (pp. 31-58). New York: Mouton de Gruyter.

Nazir, B., Aftab, U., \& Saeed, A. (2013). Language shift-The case of Punjabi in Sargodha region of Pakistan. Acta Linguistica Asiatica, 3(2), 41-60.

Nettle, D., \& Romaine, S. (2000). Vanishing voices. The extinction of the world's languages. Oxford, UK: Oxford University Press.

Pavlenko, A. (2001). Bilingualism, gender, and ideology. International Journal of Bilingualism, 5(2), 117-151.

Phillipson, R., \& Skutnabb-Kangas, T. (1995). Linguicide and linguicism. In Hans Goebl, Peter H. Nelde, Zdenek Stary, Wolfgang Wölck (Eds.), Kontaktlinguistik. Contact Linguistics. Linguistique de contact. Ein Internationales Handbuch zeitgenössiger Forschung. An International Handbook of Contemporary Research. Manuel international des recherches contemporaines. (pp. 667-675). Berlin, Germany: Walter de Gruyter.

Piller, I. (2016). Linguistic diversity and social justice: An introduction to applied sociolinguistics. Oxford: Oxford University Press.

Polkinghorne, D. E. (1989). Phenomenological research methods. In Valle, R. S., \& Halling, S. E. (Eds.), Existential-phenomenological perspectives in psychology (pp. 41-60). Boston, MA: Springer.

Qadeer, M. A. (2006). Pakistan: Social and cultural transformations in a Muslim Nation. New York: Routledge.

Rahman, T. (1996). British language policies and imperialism in India. Language Problems and Language Planning, 20(2), 91-115.

Rahman, T. (1997). Language and Ethnicity in Pakistan. Asian Survey, 37(9), 833-839. doi: $10.2307 / 2645700$ 
Rahman, T. (2005). The Muslim response to English in South Asia: With special reference to inequality, intolerance, and militancy in Pakistan. Journal of Language, Identity and Education, 4(2), 119-135.

Rahman, T. (2010). The medium of instruction controversy in Pakistan. Journal of Multilingual and Multicultural Development, 18(2), 145-154.

Rammah, S. (2006). West Punjabi Poetry: From Ustad Daman to Najm Hosain Syed. JPS, 13(1\&2), 216.

Reagan, T. (2019). Why Language Endangerment and Language Death Matter: 'Took away our native tongue... And taught their English to our young'. In Linguistic legitimacy and social justice (pp. 285-314). Palgrave Macmillan, Cham.

Romaine, S. (1995). Bilingualism. New York: Wiley-Blackwell.

Saldaña, J. (2010). The coding manual for qualitative researchers. London: Sage.

Sandberg, J. (2000). Understanding human competence at work: An interpretative approach. Academy of Management Journal, 43(1), 9-25.

Saxena, M., \& Omoniyi, T. (Eds.). (2010). Contending with globalization in world Englishes. Clevedon: Multilingual Matters.

Schubert, J. D. (2014). Suffering/symbolic violence. In M. Grenfell (Ed). Pierre Bourdieu: Key concepts (pp. 179-194). London: Routledge.

Skutnabb-Kangas, T. (1988). Multilingualism and the education of minority children. In T. Skutnabb-Kangas \& J. Cummins (Eds), Minority education: From shame to struggle, (pp. 944). Clevedon: Multilingual Matters.

Skutnabb-Kangas, T. (1999). Language attrition, language death and language murder: different facts or different ideologies. Strong' and' weak' languages in the European Union: Aspects of linguistic hegemonism, 59-73.

Shafi, A. (2013). Punjabi parents' perception of Punjabi as their children's mother tongue. Editorial Board, 39.

Simons, G., \& Fennig, C. (Eds.). (2018). Ethnologue: Languages of the world (21st ed.). Dallas, TX: SIL International. Retrieved May 6, 2018, from http://www.ethnologue.com

Viswanathan, G. (2014). Masks of conquest: Literary study and British rule in India. New York: Columbia University Press.

Walqui, A. (2000). Contextual Factors in Second Language Acquisition. ERIC Digest.

Woodrow, L. (2006). Anxiety and speaking English as a second language. RELC Journal, 37(3), 308-328.

Zaidi, A. (2010). A postcolonial sociolinguistics of Punjabi in Pakistan. Journal of Postcolonial Cultures and Societies, 1(3-4), 22-55. 